\title{
Gold and arsenic partitioning at magmatic conditions
}

\section{Other Conference Item}

\section{Author(s):}

Simon, Adam C.; Pettke, Thomas; Candela, Philip; Piccoli, Philip; Heinrich, Christoph A. (D)

Publication date:

2006-08

Permanent link:

https://doi.org/10.3929/ethz-b-000035871

\section{Rights / license:}

Creative Commons Attribution-NonCommercial-NoDerivatives 4.0 International

\section{Originally published in:}

Geochimica et Cosmochimica Acta 70(18 / Supplement), https://doi.org/10.1016/j.gca.2006.06.1097 


\title{
Gold and arsenic partitioning at magmatic conditions.
}

\author{
Adam C. Simon ${ }^{1}$, Thomas PetTKe ${ }^{2}$, Philip CANDEla ${ }^{3}$, \\ PHILIP PICCOLI ${ }^{3}$, CHRIS HEINRICH $^{4}$ \\ ${ }^{1}$ Department of Geoscience, University of Nevada, Las \\ Vegas, NV 89154-4010 USA; adam.simon@unlv.edu \\ ${ }^{2}$ University of Bern, Institute of Geological Sciences, \\ Baltzerstrasse 1-3, CH-3012, Bern, Switzerland \\ ${ }^{3}$ Department of Geology, University of Maryland, College \\ Park, MD 20742, USA \\ ${ }^{4}$ Isotope Geochemistry and Mineral Resources, Federal \\ Institute of Technology, ETH Zentrum NO, CH-8092, \\ Zurich, Switzerland
}

Gold and arsenic are associated both physically and chemically in epithermal- and porphyry-type ore deposits. There is general agreement that the $\mathrm{Au}$ and As (and other metals) in these ore deposits were precipitated from magmatic-hydrothermal aqueous fluids which themselves evolved from magmatic volatile phases exsolved directly from degassed silicate melt located stratigraphically beneath the ore zone. The behavior of Au at magmatic conditions has been the focus of two recently published studies [1,2] and data from these studies have contributed to our understanding of and ability to model the behavior of Au during the evolution of magmatic-hydrothermal systems. However, these studies were performed in sulfur-free assemblages and published data from natural fluid inclusion assemblages [3] suggest that sulfur may play a role in the partitioning behavior of Au. Additionally, there are no data constraining the behavior of As at magmatic conditions. We have acquired new data which constrain the partitioning behavior of As and $\mathrm{Au}$ in a rhyolite melt - low-salinity vapor \pm magnetite \pm pyrrhotite assemblage at $800^{\circ} \mathrm{C}, 120 \mathrm{MPa}, \mathrm{f}(\mathrm{O} 2)=\mathrm{NNO}, \log$ $\mathrm{f}(\mathrm{H} 2 \mathrm{~S})=1.1, \log \mathrm{f}(\mathrm{SO} 2)=-1.5$, and $\log \mathrm{f}(\mathrm{S} 2)=-3.0$ (i.e., po - mt at NNO). The experiments constrain the partitioning of As and the effect of sulfur on the partitioning behavior of both As and $\mathrm{Au}$ at magmatic conditions. Nernst-type partition coefficients for As remain constant with the addition of sulfur. These data suggest that As-speciation in hightemperature vapor is dominated by arsenous acid $\mathrm{As}(\mathrm{OH})_{3}$, consistent with lower temperature studies and results from SUPCRT, both of which indicate the predominance of $\mathrm{As}^{3+}$ at high temperature. Partition coefficients and apparent equilibrium constants describing the mass transfer of $\mathrm{Au}$ between melt and vapor are also unchanged with the addition of sulfur. The data suggest that the Au-scavenging potential of low-salinity vapor is not amplified by the presence of sulfur in a low $\mathrm{f}(\mathrm{S} 2)$ system even at high ratios of $\mathrm{H}_{2} \mathrm{~S}$ to $\mathrm{SO}_{2}$.

[1] Frank, M.R., Candela, P.A., Piccoli, P.M. and Glascock, M.D. (2002) Geochim. Cosmochim. Acta, 66, 3719-3732. [2] Simon, A.C., Pettke, T., Candela, P.A., Piccoli, P.M. and Heinrich, C.A. (2005) Geochim. Cosmochim. Acta, 69, 33213335. [3] Heinrich, C.A., Günther, D., Audétat, A., Ulrich, T. and Frischknecht, R. (1999) Geology, 27, 755-758. 